\title{
Recent changes in area and thickness of Torngat Mountain glaciers (northern Labrador, Canada)
}

\author{
Nicholas E. Barrand ${ }^{1}$, Robert G. Way ${ }^{2}$, Trevor Bell ${ }^{3}$, and Martin J. Sharp ${ }^{4}$ \\ ${ }^{1}$ School of Geography, Earth and Environmental Sciences, University of Birmingham, Birmingham, UK \\ ${ }^{2}$ Department of Geography, University of Ottawa, Ottawa, Canada \\ ${ }^{3}$ Department of Geography, Memorial University of Newfoundland, St. John's, Canada \\ ${ }^{4}$ Department of Earth and Atmospheric Sciences, University of Alberta, Edmonton, Canada
}

Correspondence to: Nicholas E. Barrand (n.e.barrand@bham.ac.uk)

Received: 6 July 2016 - Published in The Cryosphere Discuss.: 5 September 2016

Revised: 22 December 2016 - Accepted: 22 December 2016 - Published: 24 January 2017

\begin{abstract}
The Torngat Mountains National Park, northern Labrador, Canada, contains more than 120 small glaciers: the only remaining glaciers in continental northeast North America. These small cirque glaciers exist in a unique topoclimatic setting, experiencing temperate maritime summer conditions yet very cold and dry winters, and may provide insights into the deglaciation dynamics of similar small glaciers in temperate mountain settings. Due to their size and remote location, very little information exists regarding the health of these glaciers. Just a single study has been published on the contemporary glaciology of the Torngat Mountains, focusing on net mass balances from 1981 to 1984. This paper addresses the extent to which glaciologically relevant climate variables have changed in northern Labrador in concert with 20th-century Arctic warming, and how these changes have affected Torngat Mountain glaciers. Field surveys and remote-sensing analyses were used to measure regional glacier area loss of $27 \%$ from 1950 to 2005, substantial rates of ice surface thinning (up to $6 \mathrm{~m} \mathrm{yr}^{-1}$ ) and volume losses at Abraham, Hidden, and Minaret glaciers, between 2005 and 2011. Glacier mass balances appear to be controlled by variations in winter precipitation and, increasingly, by strong summer and autumn atmospheric warming since the early 1990s, though further observations are required to fully understand mass balance sensitivities. This study provides the first comprehensive contemporary assessment of Labrador glaciers and will inform both regional impact assessments and syntheses of global glacier mass balance.
\end{abstract}

\section{Introduction}

The glaciers of the Torngat Mountains, northern Labrador, Canada, occupy a unique physiographic and climatic setting at the southern limit of the eastern Canadian Arctic. Their proximity to the Labrador Current provides temperate, maritime summer conditions yet very cold and dry winters. Examination of Torngat glacier change may provide insights into the deglaciation dynamics of other similarly situated small-glacier populations (e.g. around the south Greenland ice sheet peripheries and Canadian Arctic Archipelago; Nilsson et al., 2015; Gardner et al., 2012) and other small glaciers retreating into cirque basins in temperate high-mountain settings (e.g. European Alps and Pyrenees, North American Rockies and Cascade Mountains). In addition, the glaciers of the Torngats contribute to the total land ice mass of very small glaciers (e.g. Bahr and Radic, 2012), are an important component of the local Arctic tundra and fjord ecosystem (Brown et al., 2012), and form part of the cultural landscape of the Labrador Inuit. Whilst early exploration and reconnaissance survey flights led to classification and mapping of some Labrador glaciers (e.g. Forbes, 1938; Henoch and Stanley, 1968), a complete inventory and analysis of the glaciers of the Torngat Mountains, covering a total active glacier area in 2005 of $22.5 \pm 1.8 \mathrm{~km}^{2}$ (not including relict ice), has only recently been completed and incorporated into global glacier datasets (Way et al., 2014; Pfeffer et al., 2014; Arendt et al., 2015). Combining the new regional glacier inventory (Way et al., 2014) with field- and remote-sensing-based analyses, Way et al. (2015) showed a consistent glacial response to centennial-scale regional climate warming by documenting 
a $52.5 \%$ reduction in ice extent since glaciers reached their Little Ice Age (LIA) maxima (dated to between 1581 and 1673).

The only other work published on the contemporary glaciology of the Torngat Mountains was based on field research expeditions conducted by Memorial University, Canada, during the early 1980s (Rogerson, 1986; Rogerson et al., 1986b). Between 1981 and 1984, these authors measured net mass balances using the glaciological method, from centreline and distributed transects of ablation stakes and snow pits, on clean and debris-covered ice at four cirque glaciers in the Selamiut Range, south of Nachvak Fjord, in the central part of the national park (Fig. 1). In all years between 1981 and 1984, the Abraham and Hidden glaciers in the adjacent McCornick River valley experienced negative net balances, ranging from -0.21 to $-1.28 \mathrm{~m} \mathrm{yr}^{-1}$ water equivalent (w.e.). Nearby higher-elevation Minaret Glacier and Superguksoak Glacier (at $1.37 \mathrm{~km}^{2}$, the largest glacier in the region) had near-zero balances in 1981, positive balances in 1982 (both $0.28 \mathrm{~m} \mathrm{yr}^{-1}$ w.e.), and slightly negative balances (both $-0.16 \mathrm{~m} \mathrm{yr}^{-1}$ w.e.) in 1983 (uncertainties are unreported). These results were linked to annual variations in winter precipitation (Rogerson, 1986). Aside from the 2005 inventory (Way et al., 2014), no more recent information is available regarding the health of these four glaciers or of the remaining glacial ice in Labrador. A key question is the extent to which glaciologically relevant climate variables in northern Labrador have changed in concert with Arctic warming during the 20th century (Kaufman et al., 2009), and how these changes have affected Labrador glaciers.

This study uses field, remote-sensing, and homogenized climate and reanalysis datasets to examine the response of glaciers in northern Labrador to prevailing climatic conditions since the mid-20th century. The 2005-dated inventory of Way et al. (2014) (derived from very high resolution aerial orthophotos) is used as a basis for historical change assessment since the mid-20th century by comparing to glacier outlines derived from archival aerial survey photography (1950). Recent glacier changes are calculated using glacier areas derived from high-resolution spaceborne electro-optical imagery (2008). Regional volume and volume change estimates are calculated using volume-area scaling relations. Field and remote-sensing surveys of ice surface topography at three of the four glaciers visited in the early 1980s are used to calculate rates of surface elevation change between 2005 and 2011, and to calculate geodetic mass balances. Finally, climate and reanalysis datasets are selected to view both 20thcentury area changes and 1980s and late-2000s glacier mass balances in the context of prevailing climatic trends. This study builds on earlier work (Brown et al., 2012; Way et al., 2014; Way et al., 2015) and provides the first comprehensive, regional-scale remote-sensing and field-based assessment of the contemporary state of Labrador glaciers and their likely climate sensitivities, the results of which may be incorpo- rated into both regional impact assessments and syntheses of global glacier mass balance.

\section{Study area and methods}

The Torngat Mountains are the southernmost mountain range in the eastern Canadian Arctic, occupying a position towards the north of the Labrador Peninsula, south of Baffin Island (Fig. 1). The synoptic climatology of the region is strongly influenced by the Labrador Current, which transports cold Arctic water into the Labrador Sea and southward along the Labrador coast (Myers and Donnelly, 2008). The influence of the Labrador Current produces maritime summer conditions and colder, drier winters due to extensive seasonal sea-ice formation (e.g. Kvamst $\varnothing$ et al., 2004). Precipitation during winter is generated by storms that are directed by the influence of the Canadian Polar Trough on the position of Arctic and polar fronts (Moore et al., 2011). Glaciers in the Torngat Mountains are preserved due to their proximity to this coastal moisture source, as well as their topographic setting (reducing incoming solar radiation receipt) and, in some cases, the insulating effect of supraglacial debris (Rogerson, 1986; Rogerson et al., 1986b; Way et al., 2014). The four glaciers measured in the early 1980s are influenced by a combination of these factors. Abraham and Hidden glaciers (Fig. 2; labelled $\mathrm{A}$ and $\mathrm{H}$ ) are less than $20 \mathrm{~km}$ from the coast, have partly debris-covered termini, and are located below $\sim 500 \mathrm{~m}$ high backwalls comprising Cirque Mountain (1568 m above sea level (a.s.1.)). Superguksoak Glacier (Fig. 2, labelled S) is similarly situated and is debris-covered over $\sim 40 \%$ of its surface area. Minaret Glacier (Fig. 2, labelled M) does not have extensive supraglacial debris cover but is located $\sim 350 \mathrm{~m}$ higher than the other glaciers and is shaded by a large backwall comprising Mount Caubvick (1652 m a.s.l.). The interplay of altitude, supraglacial debris, slope, aspect, and height of (and proximity to) cirque backwalls has been shown to influence the spatial variability of surface mass balance (Rogerson, 1986).

\subsection{Derivation of area changes}

A glacier inventory derived from late-summer (August) 2005 Parks Canada $1: 40000$-scale colour aerial photographs was used as a reference for documenting historical and late2000s glacier area changes. Full details of the 2005 inventory data collection, image processing, ice area delineation, and error assessment are provided by Way et al. (2014). Historical glacier outlines were manually digitized from 107 scanned diapositives of Royal Canadian Air Force survey photographs, acquired during a 2-week period in August 1950 (Labrador (LAB) series 47, 48, 50, 79, 91-95). Oneto-fifty-thousand-scale diapositives scanned at $1200 \mathrm{dpi}$ provided digital files with a corresponding ground pixel resolution of $\sim 1 \mathrm{~m}$. Image orthorectification in the absence of 


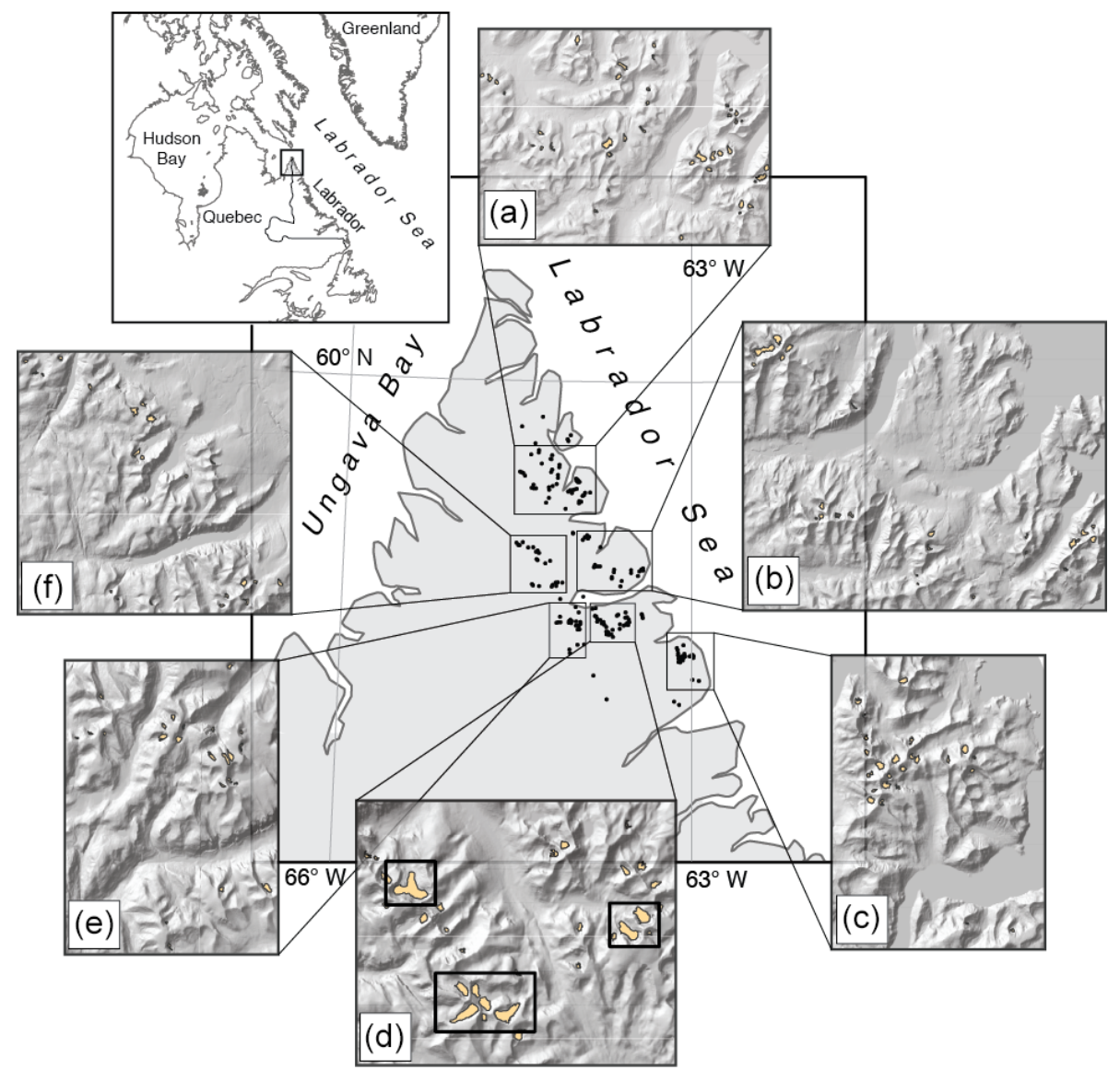

Figure 1. Locations (dots in main map) and outlines of Torngat Mountain glaciers, Labrador, Canada (upper left inset). Local glacier populations include (a) Four Peaks/Ryan's Bay; (b) Mount Tetragona/Mount Eliot/Razorback Mountain; (c) Blow Me Downs; (d) Selamiut Range/Cirque Mountain; (e) Tallek Arm; and (f) Komaktorvik Lakes. Inset map shaded relief elevations are derived from ASTER Global DEM data. Outlines in (d) refer to glacier locations in Fig. 2.

accurate camera calibration information was undertaken using a rational functions model in PCI Geomatica software (v.10.3). The model calculates correlations between image pixels and ground locations using a ratio of polynomial functions with coefficients calculated based on the number and quality of ground control points (GCPs). Between 15 and 20 GCPs per image frame were collected from 2005 orthophotos and an undated $18 \mathrm{~m}$ resolution Parks Canada digital elevation model (DEM), to correct for topographic distortion due to terrain relief (e.g. Kääb, 2005). The resulting root mean square (rms) error between the 1950 orthophotos and GCPs was $<5 \mathrm{~m}$ across all images.

To examine mid- to late-2000s area changes, scenes from the SPOT5-HRG (Satellite Pour l'Observation de la Terre High-Resolution Geometric) image archive were analysed (Table 1). The very small size of Labrador glaciers and the need to obtain both cloud and snow-free scenes during summer precluded the use of medium-resolution spaceborne visible and near-infrared sensor archives such as ASTER (Advanced Spaceborne Thermal Emission and Reflection Ra-
Table 1. SPOT5-HRG scene identification numbers and dates of image acquisition.

\begin{tabular}{ll}
\hline Scene ID & Date \\
\hline 56292290807161536431A0 & $16 / 07 / 2008$ \\
56332300807211540311A0 & $21 / 07 / 2008$ \\
56302290807251603262A3 & $25 / 07 / 2008$ \\
56302280808101555161A3 & $10 / 08 / 2008$ \\
56292280808111536031A0 & $11 / 08 / 2008$ \\
\hline
\end{tabular}

diometer) and Landsat. SPOT5-HRG images at $10 \mathrm{~m}$ ground resolution in multispectral mode (three bands between 0.50 and $0.89 \mu \mathrm{m}$ ) and $5 \mathrm{~m}$ in monospectral (panchromatic) mode $(0.51-0.73 \mu \mathrm{m})$, providing sufficient spatial resolution to accurately delineate Labrador glacier outlines following pan sharpening (e.g. Paul and Kääb, 2005; Racoviteanu et al., 2008). Cloud- and snow-free scenes used in this work were acquired during late July and early August 2008 (Table 1). 

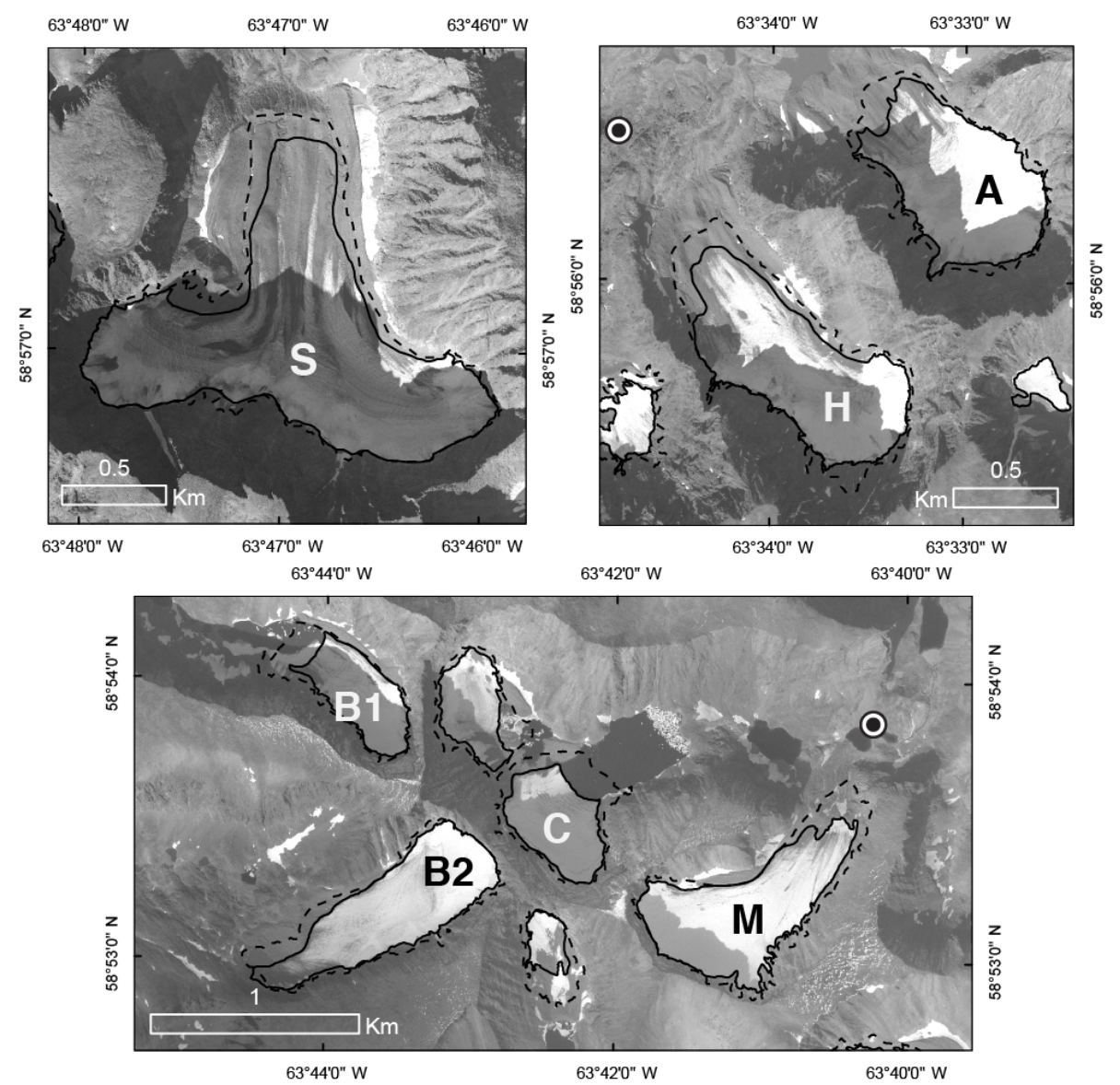

Figure 2. Areal extent of glaciers in the Selamiut Range and Cirque Mountain (see Fig. 1), in 1950 (dashed lines) and 2005 (solid lines). Background images are $1 \mathrm{~m}$ resolution Parks Canada orthophotos acquired in August 2005 (frame numbers 5026_43_4, upper left; 5022_43_136, upper right; and 5022_41_166, lower panel). Text labels refer to glacier names, as follows: S - Superguksoak; H - Hidden; A - Abraham; B1 - Bikini 1; B2 - Bikini 2; C - Caubvick; M - Minaret. Bullseye symbols denote locations of GPS base stations for topographic surveys.

Glacier extents were delineated by overlaying 2005 outlines onto 1950 and 2008 imagery sets and identifying where detectable changes had occurred (e.g. Fig. 2). Due to missing or poor-quality 1950 photo frames, outlines of 101 glaciers were digitized (out of a total of 124 active glaciers in the 2005 inventory). The areas of these 101 glaciers represent $81 \%$ of the 2005 total ice area. Due to the large swath coverage of SPOT5-HRG scenes $(60 \times 60 \mathrm{~km}$, continuous tiles), all 124 active glaciers in the 2005 inventory were successfully identified in the 2008 imagery and redigitized. Glacier outline adjustment (mapping) took place following the protocols of the Global Land Ice Measurements from Space (GLIMS) initiative (Racoviteanu et al., 2009). Indistinct and debris-covered ice margins were mapped using morphological features such as lateral meltwater streams, debris flow bands, and changes in surface slope (facilitated by three-dimensional visualization of orthophotos draped over the Parks Canada regional DEM) (e.g. Paul and Kääb, 2005; Racoviteanu et al., 2009; Way et al., 2014).
Following the approach of Paul et al. (2013), the error (precision) of glacier area delineations was determined by independent remapping of ice margins. Three separate operators mapped the extent of 10 of the largest glaciers in the region $(\sim 15 \%$ of the total ice area), selected to include a representative range of margin characteristics (bare ice, snow-covered, debris-covered, shadowed, and unshadowed). The rms difference between operator extents $(0.009$ and $0.019 \mathrm{~km}^{2}$ for 1950 and 2008 imagery) corresponds to mapping errors of $\sim 2$ and $\sim 5 \mathrm{~m}$ (equivalent buffer widths) along respective glacier margins. Buffers of \pm 5 and $\pm 10 \mathrm{~m}$ were subsequently assigned at 1950 and 2008 ice margins to account for cumulative errors in mapping, image planimetry, and orthorectification (e.g. Bolch et al., 2010; Way et al., 2014).

\subsection{Regional ice volume estimation}

Volumes of individual glaciers in 1950, 2005, and 2008 were calculated and summed regionally, using the volume- 
area $(V-A)$ power law relation: $V=c_{a} A^{\gamma}$ (e.g. Chen and Ohmura, 1990; Bahr et al., 1997). Aggregate volumes were calculated for ensembles of glaciers, as errors can be large when reported at the individual glacier scale (e.g. Chen and Ohmura, 1990). Bahr et al. (2015) note that a $1 \sigma$ error around a mean of the multiplicative scaling parameter $c_{a}$ would produce a $34 \%$ error in calculated ice volume. However, volume errors calculated by $V$ - $A$ scaling for regional-scale aggregate ensembles of glaciers are typically $<25 \%$ (Meier et al., 2007). In the absence of independent measurements of glacier volume from which to derive local scaling coefficients, $c_{a}$ was assigned equal to $0.191 \mathrm{~m}^{(3-2 \gamma)}$, and the scaling exponent was fixed to the theoretical constant $\gamma=1.375$. These values are based on worldwide means of scaling parameters and a theoretical derivation of the scaling exponent (Bahr et al., 1997, 2015).

To account for variations in the scaling parameters due to region, glacier, or other factors (spatial or temporal), uncertainties in volume (errors) were estimated by calculating volume sensitivities to the choice of scaling coefficients (e.g. DeBeer and Sharp, 2007; Barrand and Sharp, 2010). These coefficients were derived empirically from direct volume measurements of glaciers in the Alps, Cascades, and similar regions (Chen and Ohmura, 1990); of small glaciers in the Canadian Cordillera (DeBeer and Sharp, 2007); and from purely physical considerations (Bahr et al., 1997). Total volumes of all glaciers were calculated with the scaling parameters (units $\mathrm{m}^{(3-2 \gamma)}$ ) / exponents (dimensionless): $0.206 / 1.360,0.115 / 1.405$, and $0.210 / 1.360$. The maximum difference between calculated volumes was then taken as the measure of uncertainty (error) in total volume calculations (e.g. DeBeer and Sharp, 2007; Barrand and Sharp, 2010). This approach is considered preferable to a component error propagation calculation, as uncertainty in volume calculations due to the choice of scaling coefficients is likely to be an order of magnitude larger than that from the principal individual error sources (e.g. area measurement errors).

\subsection{Ice surface elevation changes}

Field surveys of glacier centreline ice surface topography were undertaken at Abraham and Hidden glaciers during August 2008, 2009, and 2011, and at Minaret Glacier during August 2008 and 2009, using dual-frequency (L1 and L2) Global Positioning System (GPS) instruments. Base-station data were collected at $1 \mathrm{~Hz}$ using tripod-mounted Leica GPS 500 receivers fixed over two survey markers drilled into exposed bedrock in the forefields of Hidden/Abraham and Minaret glaciers (for locations see Fig. 2). Ice surface topography was measured at accessible points along glacier centrelines at $\sim 5 \mathrm{~m}$ horizontal spacing using an additional GPS 500 receiver in rover mode connected to a survey-polemounted antenna. Simultaneous base-station positions were recorded during surveying to provide differential processing capability. Rover survey points were differentially corrected (including for pole height) using post-processing tools in Leica GeoOffice software. Following differential correction, positions with three-dimensional accuracy $<10 \mathrm{~cm}$ were excluded from further analysis. This procedure resulted in elimination of $\sim 15 \%$ of survey points at higher elevations proximal to cirque backwalls due to the poorer configuration of available satellites during surveying in those areas.

Elevation changes $(\delta h)$ were calculated by differencing individual crossover spot heights $(h)$ within a $1 \mathrm{~m}$ radius of the preceding year's survey position. Corrections for along- and across-track slope were deemed unnecessary due to the small crossover window size and shallow surface slopes of the accessible (and thus surveyed) parts of the ice surface (typically $<5^{\circ}$ ). Whilst some surface elevations were excluded from the difference analysis due to positional deviations from the centreline track, sufficient crossovers remained to adequately characterize centreline elevation change without the need for interpolation or plane fitting (e.g. Moholdt et al., 2010). Errors in individual crossover elevation changes were determined empirically by calculating the root sum of squares (RSS) of errors in receiver position. In addition, three-dimensional GCPs collected in 2008 over bare rock surfaces around each glacier were used to re-process 10 (Abraham and Hidden) and $5 \mathrm{~m}$ resolution (Minaret) DEMs, from 2005 Parks Canada air photos. Ice surface elevation changes were then calculated between 2005 DEM cell pixels and 2008 GPS survey positions.

\subsection{Geodetic mass balance}

Centreline ice surface elevation changes were extrapolated using glacier hyposometies to calculate geodetic mass balances from 2005 to 2008, from 2008 to 2009 (all), and from 2009 to 2011 (Abraham and Hidden glaciers only). Hypsometries were extracted from $10 \mathrm{~m}$ (Hidden and Abraham) and $5 \mathrm{~m}$ (Minaret) - posting digital elevation models of each glacier surface. DEMs were derived from stereophotogrammetric processing of 2005 aerial survey images (Way et al., 2014). Individual centreline elevation changes $(\delta h)$ were averaged into $10 \mathrm{~m}$ elevation bins and applied to all pixels in each bin across the glacier surface (e.g. Barrand et al., 2010; Nuth et al., 2010). In the event that no $\delta h$ measurements were available (due to safe-access issues during surveying or culling of low-accuracy points; see Sect. 2.3), that bin was assigned the averaged value of the next adjacent bin. Total volume changes were then calculated by multiplying $\delta h$ by the pixel area and summing across the glacier surface (e.g. Barrand et al., 2009; Barrand et al., 2010; Nuth et al., 2010). Volume changes were converted to geodetic mass balances in water equivalent units ( $\mathrm{m} \mathrm{yr}^{-1}$ w.e.) by dividing by the glacier area, assuming an ice density of $850 \pm 60 \mathrm{~kg} \mathrm{~m}^{-3}$ (Huss, 2013), and in the case of 2005-2008 and 2009-2011 measurements, dividing by the time between epochs.

Uncertainties in volume change and mass balance were calculated following an approach similar to Nuth et al. 

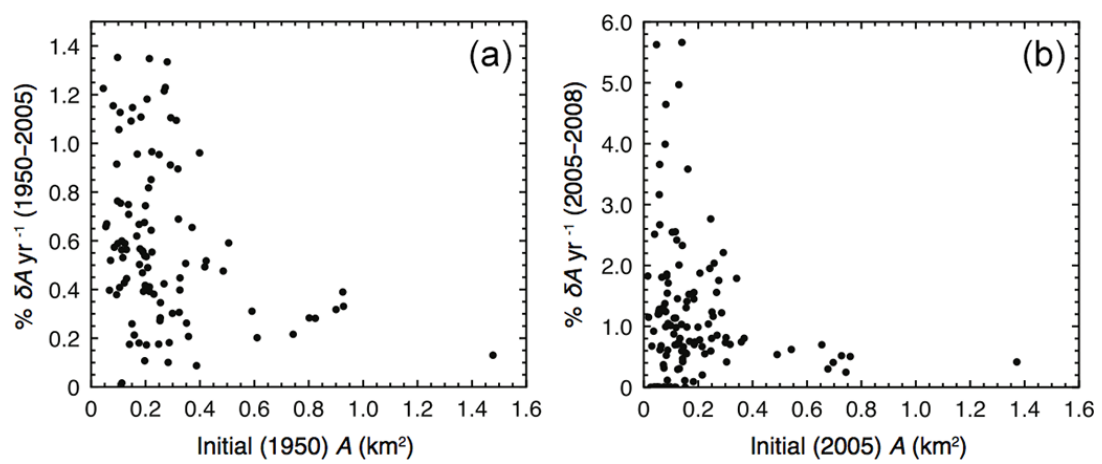

Figure 3. Annually averaged percentage glacier area loss $(\delta A)$ plotted against initial glacier area (in $\left.\mathrm{km}^{2}\right)$, between 1950 and $2005(\mathbf{a})$, and from 2005 to 2008 (b). Note difference in $y$ axis scale.

(2010). Individual point elevation change errors $\left(E_{\mathrm{PT}(\delta h)}\right)$ were calculated empirically from errors in DEM vertical accuracy or GPS receiver position (Sect. 2.3). Total elevation change errors, $E_{Z}$, were then calculated by combining $E_{\mathrm{PT}(\delta h)}$ in quadrature with extrapolation errors $\left(E_{\mathrm{EXT}}\right)$, reducing by the square root of the total number of independent measurements (e.g. Arendt et al., 2006; Barrand et al., 2010; Nuth et al., 2010), considered to be one measurement per $10 \mathrm{~m}$ elevation bin, given the presence of weakly positive spatial autocorrelation. $E_{\text {EXT }}$ quantifies the uncertainty in applying centreline $\delta h$ measurements to entire elevation bins. Following Nuth et al. (2010), $E_{\mathrm{EXT}}$ was approximated by the standard deviation of the averaged $\delta h$ in each elevation bin. Where bins had fewer than five $\delta h$ measurements, $E_{\mathrm{EXT}}$ was set to twice the glacier average, while bins with extrapolated measurements were assigned 3 times the average. Total volume change errors, $E_{\mathrm{VOL}}$, were calculated as the RSS of $E_{Z}$ multiplied by the 2005 glacier area. As all elevation measurement surveys were conducted in the same month of each year, no additional uncertainties were assigned as a result of seasonal changes.

\section{Results and discussion}

\subsection{Regional area and volume changes}

Due to missing photo frames from the 1950s LAB series, only 101 of the 124 glaciers examined in 2005 could be digitized to provide historical glacier areas. In 1950, these 101 glaciers occupied an area of $27.17 \mathrm{~km}^{2}$, shrinking to $19.78 \mathrm{~km}^{2}$ in 2005 and then $19.26 \mathrm{~km}^{2}$ in 2008: reductions of $8 \pm 0.7 \mathrm{~km}^{2}$, or $27 \%$ from 1950 to $2005\left(-0.5 \% \mathrm{yr}^{-1}\right)$, and $0.5 \pm 0.3 \mathrm{~km}^{2}$, or $1 \%$ between 2005 and $2008\left(-0.5 \% \mathrm{yr}^{-1}\right)$. During the 3 years from 2005 to 2008, the total area of all 124 glaciers in Labrador shrank from 22.46 to $21.80 \mathrm{~km}^{2}$, a reduction of $0.7 \pm 0.4 \mathrm{~km}^{2}$, or $3 \%$ of the 2005 ice area. The $27 \%$ ice area loss from 1950 to 2005 is larger than that from similarly sized glaciers between 1975 and 2000 on nearby southern Baffin Island $\left(-17 \%\right.$ for glaciers $<1 \mathrm{~km}^{2}$ ) (Paul and Svoboda, 2009). While the total Labrador glacier area loss rates are similar between periods, examination of individual annually averaged glacier losses reveals a wide range of rates of change, both within and between measurement periods (Fig. 3). Between 1950 and 2005, Labrador glaciers lost between 0.2 and $1.4 \% \mathrm{yr}^{-1}$ of their 1950 areas, with glaciers of all sizes decreasing in extent (no glacier increased in size during this period, Fig. 3a). From 2005 to 2008, 26 of the 101 glaciers $(26 \%)$ experienced zero or negligible area losses within calculated uncertainties, yet $\sim 30 \%$ of the sample experienced strongly accelerated area losses (in excess of $1 \% \mathrm{yr}^{-1}$, in several instances exceeding $5 \% \mathrm{yr}^{-1}$, Fig. 3b). These accelerated area losses between 2005 and 2008 are, however, subject to uncertainties of \pm 0.6 to $\pm 3 \% \mathrm{yr}^{-1}$.

Scaling from 101 individual glacier areas, the total volume of ice in Labrador in 1950 was $0.64 \pm 0.07 \mathrm{~km}^{3}$. Comparison of the 101 glaciers present in all three inventories showed volume changes of $-0.21 \pm 0.07 \mathrm{~km}^{3}$ between 1950 and 2005, and $-0.01 \pm 0.04 \mathrm{~km}^{3}$ between 2005 and 2008 . Between these two most recent years, uncertainties from the maximum difference between scaling coefficients (Sect. 2.2) were larger than scaled volumes as a result of the relatively small changes in glacier area. Using the average of the old and new glacier areas, the total volume change between 1950 and 2005 corresponds to an area-averaged long-term thinning rate of $-0.16 \pm 0.05 \mathrm{~m} \mathrm{yr}^{-1}$ (from $V$-A scaling). The scaled ice volumes from 124 glaciers of the complete inventories of 2005 and 2008 were respectively $0.48 \pm 0.06 \mathrm{~km}^{3}$ and $0.47 \pm 0.05 \mathrm{~km}^{3}$.

\subsection{Selamiut Range/Cirque Mountain glaciers}

Labrador's largest and only previously studied glaciers are situated in the Selamiut Range and proximal to Cirque Mountain, south of Nachvak Fjord (Figs. 1, 2). Focusing on the four sites visited in the early 1980s, Superguksoak Glacier (the largest glacier in Labrador) decreased in size from $1.47 \pm 0.08 \mathrm{~km}^{2}$ in 1950 to $1.37 \pm 0.03 \mathrm{~km}^{2}$ in $2005(-7 \%)$ and then further to $1.35 \pm 0.11 \mathrm{~km}^{2}$ in 

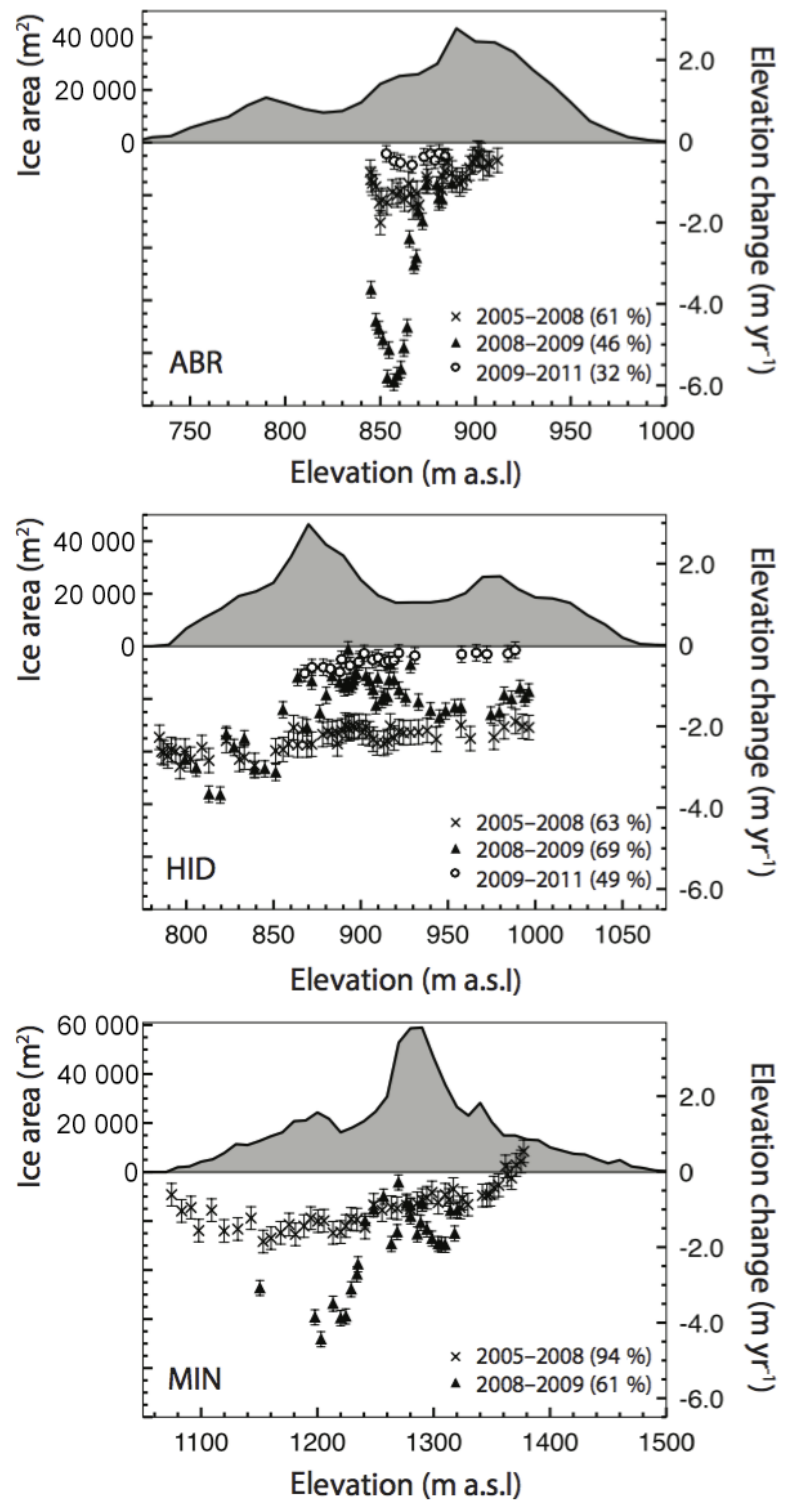

Figure 4. Hypsometry (filled line plots) and ice surface elevation change rates between 2005 and 2008 (crosses), and 2008 and 2009 (triangles) at Abraham (ABR), Hidden (HID), and Minaret (MIN) glaciers, and from 2009 to 2011 (circles) at Abraham and Hidden glaciers. Error bars are $1 \sigma$ errors, determined empirically using DEM vertical errors and errors in GPS receiver position. The percentage area surveyed (ratio of the total area of altitude bands containing at least one elevation change measurement to the total glacier area) are given for each time period, following the symbol legend.

$2008(-8 \%)$. Hidden and Abraham glaciers shrank from $0.74 \pm 0.04 \mathrm{~km}^{2}$ and $0.61 \pm 0.03 \mathrm{~km}^{2}$ in 1950 to $0.65 \pm 0.03$ and $0.54 \pm 0.02 \mathrm{~km}^{2}$ in 2005 (-12 and $-11 \%$, respectively), and then to $0.64 \pm 0.04$ and $0.53 \pm 0.04 \mathrm{~km}^{2}$ in $2008(-14$ and $-13 \%$, respectively). Finally, Minaret Glacier reduced in size from $0.92 \pm 0.05 \mathrm{~km}^{2}$ in 1950 to $0.73 \pm 0.02 \mathrm{~km}^{2}$ in
$2005(-21 \%)$, and then $0.71 \pm 0.05 \mathrm{~km}^{2}$ in $2008(-23 \%)$ (Fig. 2). Although no area increases were observed, it is important to note that individual year measurements may mask considerable interannual variability in glacier area change (including the possibility of glacier growth resulting from positive-mass-balance years) (e.g. Rogerson, 1986).

Hypsometries derived from 2005 stereo-photogrammetric DEMs reveal the area-altitude distributions of Abraham, Hidden, and Minaret glaciers (Fig. 4). Abraham and Hidden have bimodal hypsometric distributions, with peaks at $\sim 800$ and $900 \mathrm{~m}$ a.s.l. at Abraham, and $~ 875$ and $975 \mathrm{~m}$ a.s.l. at Hidden Glacier, and no sustained accumulation zone. In contrast, all of the ice of Minaret Glacier exists at higher elevations than Hidden and Abraham, predominantly between 1250 and $1350 \mathrm{~m}$ a.s.l. Rates of ice surface elevation change varied between glaciers, and particularly between measurement intervals (Fig. 4). From 2005 to 2008, Abraham, Hidden, and Minaret glaciers thinned at average rates of $-0.98,-2.32$, and $-0.93 \mathrm{~m} \mathrm{yr}^{-1}$, respectively. Between 2008 and 2009, the largest thinning rates were measured at Abraham Glacier (up to $6 \mathrm{myr}^{-1}$ at $850 \mathrm{~m}$ a.s.1.). These very large thinning rates (compared to resultant area changes) decreased further up-glacier yet remained around $1 \mathrm{~m} \mathrm{yr}^{-1}$ at higher elevations. Over the same time period, Hidden Glacier, which has a similar area-altitude distribution to Abraham yet is more extensively shaded and debris-covered, experienced slightly lower thinning rates, up to $4 \mathrm{~m} \mathrm{yr}^{-1}$ at lower elevations and $1-2 \mathrm{~m} \mathrm{yr}^{-1}$ above $\sim 860 \mathrm{~m}$ a.s.1. This elevation-dependant control on valley glacier elevation change was also observed between 2005 and 2008 at all glaciers, and between 2008 and 2009 at Minaret Glacier, with substantial thinning $\left(\sim 4 \mathrm{~m} \mathrm{yr}^{-1}\right)$ again at lower elevations (1200 $\mathrm{m}$ a.s.1.), decreasing to $1-2 \mathrm{~m} \mathrm{yr}^{-1}$ above $\sim 1250 \mathrm{~m}$ a.s.l. Thinning rates at Abraham and Hidden glaciers were greatly reduced during the period 2009-2011. While relatively few measurements of elevation change were available at Abraham Glacier, they provided an average thinning rate of $0.47 \pm 0.22 \mathrm{~m} \mathrm{yr}^{-1}$. An elevation-dependent thinning rate was observed at Hidden Glacier between 2009 and 2011 , decreasing from $1 \mathrm{~m} \mathrm{yr}^{-1}$ at lower elevations to $0.2 \mathrm{~m} \mathrm{yr}^{-1}$ at $1000 \mathrm{~m}$ a.s.l. (Fig. 4). The large thinning rates measured at Abraham, Hidden, and Minaret glaciers between 2008 and 2011 far exceed the area-averaged longterm (1950-2005) thinning rate from volume-area scaling $\left(-0.16 \pm 0.05 \mathrm{~m} \mathrm{yr}^{-1}\right)$.

The thinning rates observed between the summers of 2005 , 2008, 2009, and 2011 correspond to negative geodetic mass balances at Abraham, Hidden, and Minaret glaciers between 2005 and 2011. Strongly negative balances between 2005 and 2008, and 2008 and 2009 coincided with nonexistent or very small accumulation areas at these glaciers, as evidenced by the low-snow summer ice conditions present in 2005 aerial photographs, and during 2008 and 2009 field seasons. At Abraham Glacier, mass balances were $-0.71 \pm 0.43$, $-1.72 \pm 0.41$, and $-0.36 \pm 0.37 \mathrm{~m} \mathrm{yr}^{-1}$ w.e. between 2005 

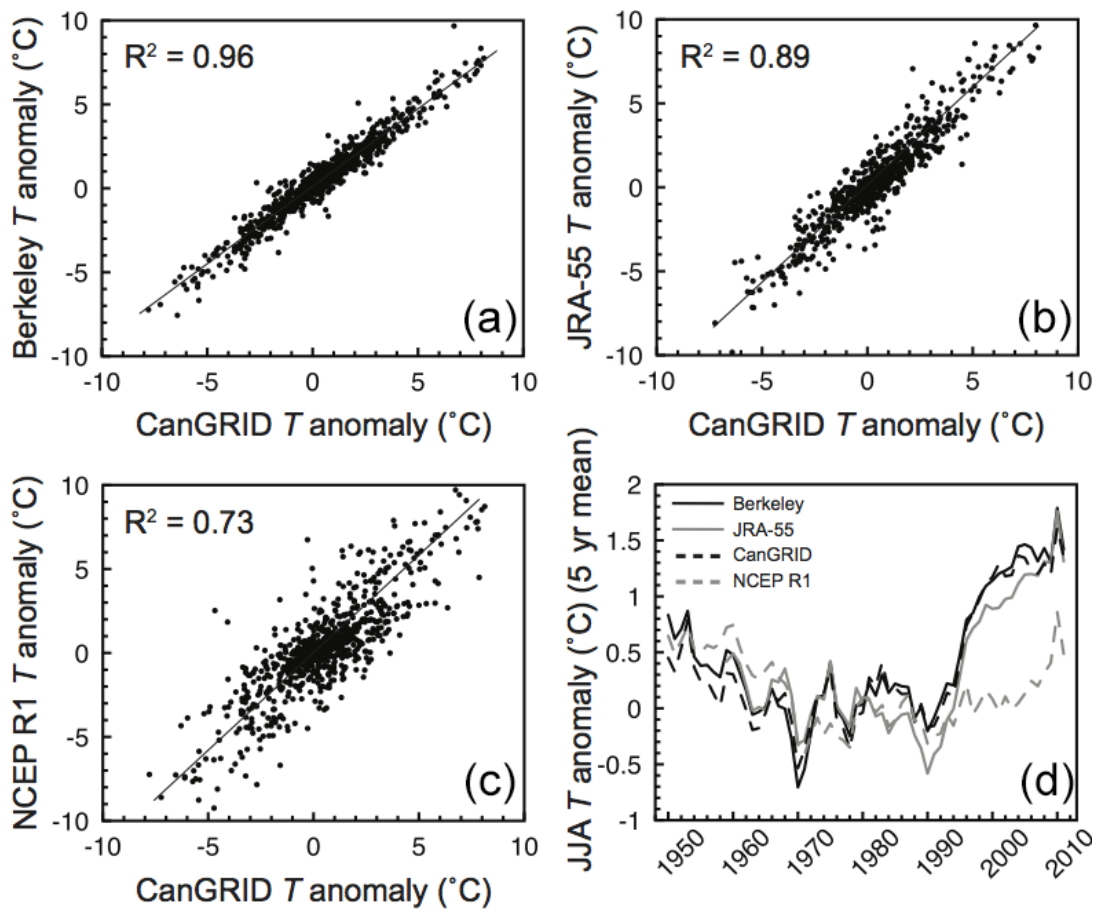

Figure 5. CanGRID $2 \mathrm{~m}$ air temperature ( $T$ ) anomalies plotted as a function of Berkeley Earth (a), JRA-55 (b), and NCEP R1 (c) anomalies. Solid lines represent linear regression lines. Data were extracted for all available years and averaged across the region $58-60^{\circ} \mathrm{N}, 295-297^{\circ} \mathrm{E}$. Panel (d) shows smoothed summer (JJA) $T$ anomalies from each dataset, between 1950 and 2011.

and 2008, 2008 and 2009, and 2009 and 2011. For the same time periods, balances at Hidden Glacier were $-1.83 \pm 0.19$, $-1.18 \pm 0.23$, and $-0.23 \pm 0.19 \mathrm{~m} \mathrm{yr}^{-1}$ w.e., and at Minaret Glacier $-0.24 \pm 0.13$ and $-1.45 \pm 0.27 \mathrm{~m} \mathrm{yr}^{-1}$ w.e. (20052008 and 2008-2009 only). Considering uncertainties, small mass balance values from 2010 to 2011 may be considered as close to zero rather than negative. The larger uncertainties associated with Abraham and Minaret Glacier balances reflect the relative paucity of available elevation change measurements at these sites, largely a result of safe-access issues during surveying at lower elevations and poor GPS satellite coverage within the upper cirque basins.

While geodetic balances are available for years between 2005 and 2011 only, they may be compared with net balances from field measurements obtained in the early 1980s. Net balances at Abraham Glacier in the balance years 1981, 1982 , and 1983 were $-0.27,-0.46$, and $-1.28 \mathrm{~m} \mathrm{yr}^{-1}$ w.e. (Rogerson, 1986). The geodetic balance measured between 2008 and $2009\left(-1.72 \pm 0.41 \mathrm{~m} \mathrm{yr}^{-1}\right.$ w.e. $)$ is thus the most negative mass balance yet recorded at this glacier. The 2005-2008 geodetic balance at neighbouring Hidden Glacier $\left(-1.83 \pm 0.19 \mathrm{~m} \mathrm{yr}^{-1}\right.$ w.e. $)$ is more negative than any balance year during the early 1980s (1981, 1982, and 1983: $-0.24,-0.21$, and $-0.81 \mathrm{~m} \mathrm{yr}^{-1}$ w.e., respectively) and is the most negative balance yet recorded at this or any other glacier in Labrador. This strongly negative post-2005 mass balance is similar in magnitude to that measured at nearby
Terra Nivea ice cap on southern Baffin Island (Papasodoro et al., 2015). While these 6 years of discontinuous measurements represent the only geodetic mass balance observations yet recorded at Labrador glaciers, it is important to note that they may mask considerable interannual variability in accumulation and ablation at the sampled glaciers and within the wider regional population.

\subsection{Climatological drivers}

Two gridded observation-based climate datasets and two reanalysis products were selected to provide a northern Labrador climatological context for the late-20th- and 21stcentury glaciological observations. Seasonal $2 \mathrm{~m}$ air temperatures and precipitation totals (where available) were extracted from the homogenized observational datasets CanGRID and Berkeley Earth (Zhang et al., 2010; Rohde et al., 2013), and from the NCEP/NCAR R1 and JRA-55 reanalysis products (Kalnay et al., 1996; Kobayashi et al., 2015). An intercomparison of these observational data and reanalyses is worthwhile as both approaches and products have data coverage over northern Labrador yet utilize different input data and interpolation schemes. They may also vary in time period, domain, and spatial resolution. A more detailed overview of widely used surface-based and reanalysis datasets for temperature and precipitation trend analysis in the wider Canadian Arctic is provided by Rapaic et al. (2015). Following Rapaić et al. (2015), Berkeley Earth, 

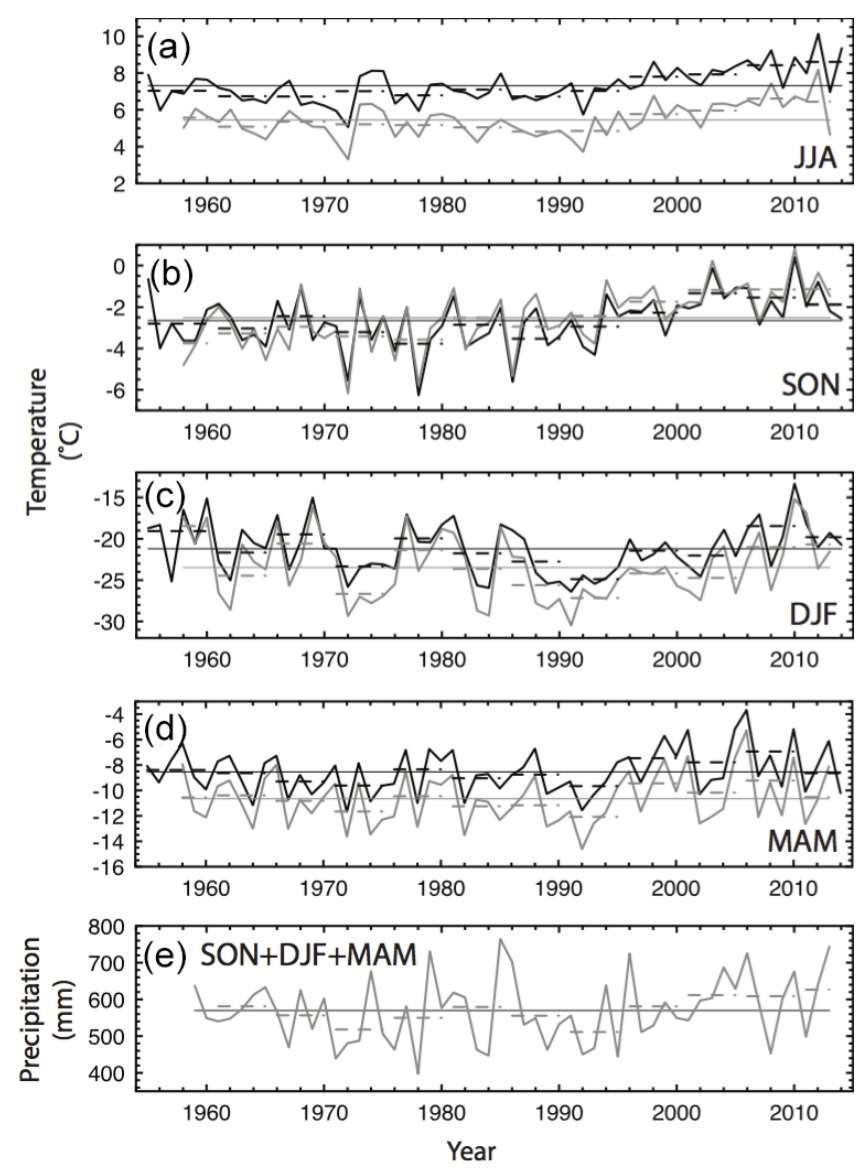

Figure 6. Time series of seasonal $2 \mathrm{~m}$ air temperatures (a-d), and preceding accumulation season (September-May) precipitation totals (e), averaged across the region $58-60^{\circ} \mathrm{N}, 295-297^{\circ} \mathrm{E}$, from Berkeley Earth (black lines) and JRA-55 reanalysis datasets (grey lines). Continuous solid lines are time-series averages, and dashed line segments are pentadal means.

NCEP R1, and JRA-55 temperature anomalies were evaluated for the Torngat Mountains region $\left(58-60^{\circ} \mathrm{N}, 295-\right.$ $297^{\circ} \mathrm{E}$ ) using the CanGRID dataset as a reference. The strongest regression model fit was found between CanGRID and observation-based Berkeley Earth temperature anomalies $\left(r^{2}=0.96\right.$, Fig. 5a). The best model fit between CanGRID and reanalysis temperature anomalies was JRA-55 $\left(r^{2}=0.89\right)$, with noticeably less spread and a better model fit than NCEP R1 $\left(r^{2}=0.73\right.$, Fig. 5b, c). A time-series plot of summer (JJA) $2 \mathrm{~m}$ air temperature anomalies in the Torngat Mountains from all four products confirmed the 20thcentury Arctic summer warming trend (mean of $0.85^{\circ} \mathrm{C}$ between 1990 and 2011) (e.g. Rapaić et al., 2015) yet showed a clear cold-temperature bias in NCEP R1 since the mid-1990s (Fig. 5d). Due to this bias and their stronger regression model fits to CanGRID reference data, Berkeley Earth (global availability) and JRA-55 (including precipitation) were selected for further examination of seasonal climate indices.
Time-series plots of seasonal $2 \mathrm{~m}$ air temperatures (JJA, SON, DJF, MAM) and total accumulation season precipitation $(\mathrm{SON}+\mathrm{DJF}+\mathrm{MAM})$ were created to examine seasonal climatic conditions in the Torngat Mountains for the period associated with glacier change measurements (1950-2015). Seasonal temperatures were most similar between Berkeley Earth and JRA-55 datasets in autumn (Fig. 6b) and showed similar interannual variability yet $1-2{ }^{\circ} \mathrm{C}$ magnitude temperature difference for summer, winter, and spring seasons (Fig. 6a, c-d). Each of the time series showed long-term warming trends, superimposed with interannual and pentadscale variability, consistent with observations throughout the rest of the province of Labrador (Finnis and Bell, 2015; Way and Viau, 2015). Warming trends were most pronounced during summer and autumn after 1990 (Fig. 6a-b). Winter temperatures decreased between 1950 and 1990, before rising again post-1990 (Fig. 6c). The post-1990 warming may in part explain individual years of negative mass balance in the late 2000s. Total ablation season precipitation from JRA-55 reanalysis shows 8 years of above-average precipitation between 1974 and 1986, and then a slightly increasing precipitation trend since the early 1990s (Fig. 6e). Year-to-year variability in climate-mass balance linkages are presented in Fig. 7.

While these climate data are both temporally and spatially averaged and thus may not be representative of climate conditions at individual glaciers, it is possible to examine seasonal temperature and precipitation trends in order to suggest potential drivers of glacier change. Glaciers in Labrador lost $27 \%$ of their surface area between 1950 and 2005. As both Berkeley Earth and JRA-55 show largely stable seasonal temperatures between 1950 and the early 1990s, it may be suggested that a majority of this area loss occurred after 1990. Pentadal means of seasonal air temperatures from both records show summer and autumn warming of around $2{ }^{\circ} \mathrm{C}$ by $2010-2015$, compared to pre-1995 levels (Fig. 6a, b). This summer warming suggests greater energy available for ablation season melt, while warmer autumn temperatures (which include several seasonal average temperatures above $0{ }^{\circ} \mathrm{C}$ ) may also indicate an increasing proportion of winter precipitation falling as rain.

The field mass balance measurements of Rogerson (1986), which included years of positive mass balance, were explained by the author in terms of variability in winter snowfall - a finding supported by the precipitation data presented here. JRA-55 precipitation totals during 1976-1985 pentads were $\sim 8$ and $12 \%$ greater (in 1976-1980 and 1981-1985, respectively) than the preceding pentadal period (1971-1975) (Fig. 6e). The only year of negative mass balance at all four glaciers (1983, mean net balance of $-0.60 \mathrm{~m} \mathrm{yr}^{-1}$ w.e.) coincided with a very low precipitation total during the accumulation season $(462 \mathrm{~mm})$. Figure 7 shows 2005-2011 geodetic mass balance results alongside JRA-55 seasonal temperature and precipitation trends. These plots show less negative balances at Abraham and Minaret 

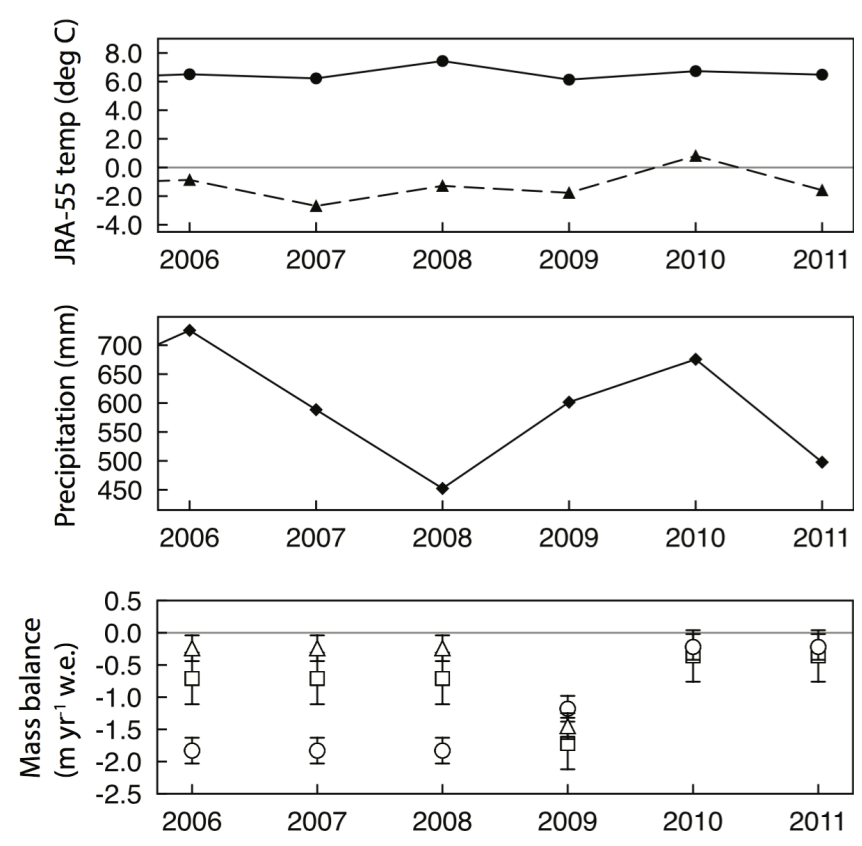

Figure 7. Time series of JRA-55 seasonal air temperatures (upper panel: JJA, solid line and dots; SON, dashed line and triangles), JRA-55 precipitation (middle panel, diamonds), and geodetic mass balances (lower panel) at Abraham (squares), Hidden (circles), and Minaret (triangles) glaciers, between 2005/2006 and 2011. Note that 2005-2008 and 2009-2011 values are annually averaged, calculated between geodetic measurements at the start and end of both periods.

glaciers between 2005 and 2008, following a high precipitation total of $726 \mathrm{~mm}$ in 2006. Larger negative balances at Hidden glacier during this time period may suggest greater insensitivity to precipitation. Geodetic balances more negative than $-1 \mathrm{~m} \mathrm{yr}^{-1}$ w.e. at all glaciers between 2008 and 2009 followed a low precipitation total of $452 \mathrm{~mm}$ during the 2007-2008 winter (which may explain the 2008 snowfree summer ice conditions), and summer temperatures more than $1{ }^{\circ} \mathrm{C}$ warmer than the $2005-2010$ pentadal mean (itself $1{ }^{\circ} \mathrm{C}$ higher than the 1950-2015 mean) (Fig. 6). The lower thinning rates and less negative geodetic balances at Abraham and Hidden glaciers between 2009 and 2011 follow precipitation totals some 17 and $22 \%$ greater than the preceding year (2008) accumulation season total (Fig. 6e), and an extended ablation season with melting conditions extending into the September-November period during 2010 (Fig. 6b). While only tentative climate-mass balance linkages may be drawn from these limited data, interannual variability in winter precipitation and post-1995 climate warming may play important roles in contemporary Labrador glacier mass changes (similar to many other Northern Hemisphere mountain glacier systems). Longer mass balance records with improved temporal resolution and more local-scale climatological observations are required to confirm these findings.

\section{Summary and conclusions}

This study presents the first comprehensive analysis of the contemporary state of small glaciers in the remote Torngat Mountains of northern Labrador, Canada. These glaciers occupy a unique position as the most southerly ice masses in the eastern Canadian Arctic. Very little was previously known about the recent status of Labrador glaciers, with a single study published on the mass balance of four glaciers during the early 1980s. Due to their very small sizes and remote locations, analysis of Labrador glacier change required an experimental design comprising both detailed field observations and high-resolution remote-sensing image analysis. Glaciers in Labrador lost $27 \%$ of their surface area between 1950 and 2005, a larger proportional loss than that from similarly sized glaciers in nearby southern Baffin Island over the same period. They then shrunk a further $3 \%$ to $21.80 \pm 2.2 \mathrm{~km}^{2}$ by 2008 , with an associated (scaled) total ice volume of $0.47 \pm 0.05 \mathrm{~km}^{3}$. Three cirque glaciers measured in the early 1980s and revisited from 2008 to 2011 thinned at rates between 0.5 and $6 \mathrm{~m} \mathrm{yr}^{-1}$ at lower elevations at measurement periods between 2005 and 2011, mostly in excess of the long-term (1950-2005) thinning rate derived from volume-area scaling $\left(-0.16 \pm 0.05 \mathrm{~m} \mathrm{yr}^{-1}\right)$. These very high thinning rates resulted in consistently negative geodetic balances at all three glaciers between 2005 and 2011 , with a balance of $-1.83 \pm 0.19 \mathrm{~m} \mathrm{yr}^{-1}$ w.e. at Hidden Glacier between 2005 and 2008 being the most negative mass balance yet recorded at this or any other glacier in Labrador, and similar in magnitude to that measured at nearby Terra Nivea ice cap. Both geodetic balances between 2005 and 2011 and net balances from early-1980s field measurements were linked to prevailing climatic conditions from gridded observational and reanalysis-based climate datasets. These findings suggested that Labrador glacier mass trends may be controlled by variability in winter precipitation, and increasingly by strong summer and autumn atmospheric warming since the early 1990s, though further observations are required to confirm these linkages.

\section{Data availability}

Datasets are available from the corresponding author on request.

Acknowledgements. Access to SPOT5-HRG scenes, digital orthophotos, diapositives, and prints was provided by Parks Canada, the National Air Photo Library (NAPL, Ottawa), and the National Hydrological Research Institute (NHRI, Saskatoon). We thank the staff and employees of Parks Canada for access and logistical support, and J. King, P. LeBlanc, A. Tuglavina, and E. Merkuratsuk for assistance in the field. ASTER GDEM is a product of METI and NASA, and it is available for download from http://gdem.ersdac.jspacesystems.or.jp. Climate data were accessed via the University of Maine, USA, Climate Change 
Institute (CCI) Climate Reanalyzer: http://cci-reanalyzer.org. This work was supported by grants to T. Bell from ArcticNet, a Network of Centres of Excellence of Canada, and M. J. Sharp from the Government of Canada International Polar Year Program. We thank the editor, Etienne Berthier, and referees, Mauri Pelto and Finnur Pálsson, for comments which improved the manuscript.

Edited by: E. Berthier

Reviewed by: M. Pelto and F. Pálsson

\section{References}

Arendt, A., Echelmeyer, K., Harrison, W., Lingle, C., Zirnheld, S., Valentine, V., Ritchie, B., and Druckenmiller, M.: Updated estimates of glacier volume changes in the western Chugach Mountains, Alaska, and a comparison of regional extrapolation methods, J. Geophys. Res., 111, F03019, doi:10.1029/2005JF000436, 2006.

Arendt, A. and The Randolph Consortium: Randolph Glacier Inventory - A Dataset of Global Glacier Outlines: Version 5.0, Global Land Ice Measurements from Space, Boulder, Colorado, Digital Media, 2015.

Bahr, D. B. and Radic, V.: Significant contribution to total mass from very small glaciers, The Cryosphere, 6, 763-770, doi:10.5194/tc-6-763-2012, 2012.

Bahr, D. B., Meier, M. F., and Peckham, S. D.: The physical basis of glacier volume-area scaling, J. Geophys. Res., 102, 355-362, 1997.

Bahr, D. B., Pfeffer, W. T., and Kaser, G.: A review of volume-area scaling of glaciers, Rev. Geophys., 53, 95-140, doi:10.1002/2014RG000470, 2015.

Barrand, N. E. and Sharp, M. J.: Sustained rapid shrinkage of Yukon glaciers since the 1957-1958 International Geophysical Year, Geophys. Res. Lett., 37, L07501, doi:10.1029/2009GL042030, 2010.

Barrand, N. E., Murray, T., James, T. D., Barr, S. L., and Mills, J. P.: Optimizing photogrammetric DEMs for glacier volume change assessment using laser-scanning derived ground-control points, J. Glaciol., 55, 106-116, doi:10.3189/002214309788609001, 2009.

Barrand, N. E., James, T. D., and Murray, T.: Spatio-temporal variability in elevation changes of two high-Arctic valley glaciers, J. Glaciol., 56, 771-780, doi:10.3189/002214310794457362, 2010.

Bolch, T., Menounos, B., and Wheate, R.: Landsat-based inventory of glaciers in western Canada, 1985-2005, Remote Sens. Environ., 114, 127-137, doi:10.1016/j.rse.2009.08.015, 2010.

Brown, R. B., Lemay, M., Allard, M., Barrand, N. E., Barette, C., Begin, Y., Bell, T., Bernier, M., Bleau, S., Chaumont, D., Dibike, Y., Frigon, A., Leblanc, P., Paquin, D., Sharp, M. F., and Way, R.: Climate variability and change in the Eastern Canadian Subarctic IRIS region (Nunavik and Nunatsiavut), in: Nunavik and Nunatsiavut: From science to policy: An integrated regional impact study (IRIS) of climate change and modernization, edited by: Allard, M. and Lemay, M., ArcticNet, Québec, Laval University, doi:10.13140/RG.2.1.3745.0323, 2012.
Chen, J. and Ohmura, A.: Estimation of alpine glacier water resources and their change since the 1870s, in: IAHS Publication 193, 127-135, IAHS, 1990.

DeBeer, C. M. and Sharp, M. J.: Recent changes in glacier area and volume within the southern Canadian Cordillera, Ann. Glaciol., 46, 215-221, doi:10.3189/172756407782871710, 2007.

Finnis, J. and Bell, T.: An analysis of recent observed climate trends and variability in Labrador, Can. Geogr., 59, 151-166, doi:10.1111/cag.12155, 2015.

Forbes, A.: Northernmost Labrador mapped from the air, American Geographical Society, Special publication number 22, 255 pp., 1938.

Gardner, A., Moholdt, G., Arendt, A., and Wouters, B.: Accelerated contributions of Canada's Baffin and Bylot Island glaciers to sea level rise over the past half century, The Cryosphere, 6, 11031125, doi:10.5194/tc-6-1103-2012, 2012.

Henoch, W. E. and Stanley, A.: Glacier map of southern Baffin Island (District of Franklin) and the Northern Labrador Peninsula, Glaciology Subdivision, Inland Waters Branch, Department of Energy, Mines and Resources, Ottawa, Canada, 1968.

Huss, M.: Density assumptions for converting geodetic glacier volume change to mass change, The Cryosphere, 7, 877-887, doi:10.5194/tc-7-877-2013, 2013.

Kääb, A.: Remote sensing of mountain glaciers and permafrost creep, Schriftenreihe Physische Geographie, Geographisches Institut der Universität Zürich, Zürich, 48, 266 pp., 2005.

Kalnay, E., Kanamitsu, M., Kistler, R., Collins, W., Deaven, D., Gandin, L., Iredell, M., Saha, S., White, G., Woollen, J., Zhu, Y., Leetmaa, A., Reynolds, R., Chelliah, M., Ebisuzaki, W., Higgins, W., Janowiak, J., Mo, K. C., Ropelewski, C., Wang, J., Jenne, R., and Joseph, D.: The NCEP/NCAR 40-year reanalysis project, B. Am. Meteorol. Soc., 77, 437-471, doi:10.1175/15200477(1996)077, 1996.

Kaufman, D., Schneider, D. P., McKay, N. P., Ammann, C. M. Bradley, R. S., Briffa, K. R., Miller, G. H., Otto-Bliesner, B. L., Overpeck, J. T., Vinther, B. M., and Arctic Lakes 2k Project Members: Recent warming reverses long-term Arctic cooling, Science, 325, 1236-1239, doi:10.1126/science.1173983, 2009.

Kobayashi, S., Ota, Y., Harada, Y., Ebita, A., Moriya, M., Onoda, H., Onogi, K., Kamahori, H., Kobayashi, C., Endo, H., Miyaoka, K., and Takahashi, K.: The JRA-55 Reanalysis: General specifications and basic characteristics, J. Meteorol. Soc. Jpn., 93, 5-48, doi:10.2151/jmsj.2015-001, 2015.

Kvamstø, N. G., Skeie, P., and Stephenson, D. B.: Impact of Labrador sea-ice extent on the North Atlantic Oscillation, Int. J. Climatol., 24, 603-612, 2004.

Meier, M. F., Dyurgerov, M., Rick, U., O’Neel, S., Pfeffer, W. T., Anderson, R. S., Anderson, S., and Glazovsky, A.: Glaciers dominate eustatic sea-level rise in the 21 st century, Science, 317, 1064-1067, doi:10.1126/science.1143906, 2007.

Moholdt, G., Nuth, C., Hagen, J. O., and Kohler, J.: Recent elevation changes of Svalbard glaciers derived from ICESat laser altimetry, Remote Sens. Environ., 114, 2756-2767, doi:10.1016/j.rse2010.06.008, 2010.

Moore, G. W. K., Pickart, R. S., and Renfrew, I. A.: Complexities in the climate of the subpolar North Atlantic: a case study from the winter of 2007, Q. J. Roy. Meteor. Soc., 137, 757-767, doi:10.1002/qj.778, 2011. 
Myers, P. and Donnelly, C.: Water mass transformation and formation in the Labrador Sea, J. Climate, 21, 1622-1638, 2008.

Nilsson, J., Sandberg Sørensen, L., Barletta, V. R., and Forsberg, R.: Mass changes in Arctic ice caps and glaciers: implications of regionalizing elevation changes, The Cryosphere, 9, 139-150, doi:10.5194/tc-9-139-2015, 2015.

Nuth, C., Moholdt, G., Kohler, J., Hagen, J. O., and Kääb, A.: Svalbard glacier elevation changes and contribution to sea level rise, J. Geophys. Res., 115, F01008, doi:10.1029/2008JF001223, 2010.

Papasodoro, C., Berthier, E., Royer, A., Zdanowicz, C., and Langlois, A.: Area, elevation and mass changes of the two southernmost ice caps of the Canadian Arctic Archipelago between 1952 and 2014, The Cryosphere, 9, 1535-1550, doi:10.5194/tc9-1535-2015, 2015.

Paul, F. and Kääb, A.: Perspectives on the production of a glacier inventory from multispectral satellite data in Arctic Canada: Cumberland Peninsula, Baffin Island, Ann. Glaciol., 42, 59-66, doi:10.3189/172756405781813087, 2005.

Paul, F. and Svoboda, F.: A new glacier inventory on southern Baffin Island, Canada, from ASTER data: II. Data analysis, glacier change and applications, Ann. Glaciol., 50, 22-31, doi:10.3189/172756410790595921, 2009.

Paul, F., Barrand, N. E., Baumann, S., Berthier, E., Bolch, T., Casey, K., Frey, H., Joshi, S. P., Konovalov, V., Le Bris, R., Mölg, N., Nosenko, G., Nuth, C., Pope, A., Racoviteanu, A., Rastner, P., Raup, B., Scharrer, K., Steffen, S., and Winsvold, S.: On the accuracy of glacier outlines derived from remote sensing data, Ann. Glaciol., 54, 171-182, doi:10.3189/2013AoG63A296, 2013.

Pfeffer, W. T., Arendt, A. A., Bliss, A., Bolch, T., Cogley, J. G., Gardner, A. S., Hagen, J. O., Hock, R., Kaser, G., Kienholz, C., Miles, E. S., Moholdt, G., Molg, N., Paul, F., Radic, V., Rastner, P., Raup, B. H., Rich, J., Sharp, M. J., and The Randolph Consortium: The Randolph Glacier Inventory: a globally complete inventory of glaciers, J. Glaciol., 60, 537-552, doi:10.3189/2014JoG13J176, 2014.

Racoviteanu, A. E., Arnaud, Y., Williams, M. W., and Ordonez, J.: Decadal changes in glacier parameters in the Cordillera Blanca, Peru, derived from remote sensing, J. Glaciol., 54, 499-510, doi:10.3189/002214308785836922, 2008.
Racoviteanu, A. E., Paul, F., Raup, B., Khalsa, S. J. S., and Armstrong, R.: Challenges and recommendations in mapping of glacier parameters from space: results of the 2008 Global Land Ice Measurements from Space (GLIMS) workshop, Boulder, Colorado, USA, Ann. Glaciol., 50, 53-69, doi:10.3189/172756410790595804, 2009.

Rapaić, M., Brown, R., Markovic, M., and Chaumont, D.: An evaluation of temperature and precipitation surface-based and reanalysis datasets for the Canadian Arctic, 1950-2010, Atmos.-Ocean, 53, 283-303, 2015.

Rogerson, R. J.: Mass balance of four cirque glaciers in the Torngat Mountains of Northern Labrador, Canada, J. Glaciol., 32, 208218, 1986.

Rogerson, R. J., Evans, D. J. A., and McCoy, W. D.: Five year growth of rock lichens in a low-Arctic mountain environment, Labrador, Canada, Geographie Physique et Quaternaire, 40, 8591, 1986a.

Rogerson, R. J., Olson, M. E., and Branson, D.: Medial moraines and surface melt on glaciers of the Torngat Mountains, Northern Labrador, Canada, J. Glaciol., 32, 350-354, 1986b.

Rohde, R., Muller, R., Jacobsen, R., Muller, E., Perlmutter, S., Rosenfeld, A., Wurtele, J., Groom, D., and Wickham, C.: A new estimate of the average Earth surface land temperature spanning 1753 to 2011, Geoinformatics and Geostatistics: An Overview, 1, 1-7, doi:10.4172/2327-4581.1000101, 2013.

Way, R. G. and Viau, A. E.: Natural and forced air temperature variability in the Labrador region of Canada during the past century, Theor. Appl. Climatol., 121, 413-424, doi:10.1007/s00704-0141248-2, 2015.

Way, R. G., Bell, T., and Barrand, N. E.: An inventory and topographic analysis of glaciers in the Torngat Mountains, northern Labrador, Canada, J. Glaciol., 60, 945-956, doi:10.3189/2014JoG13J195, 2014.

Way, R. G., Bell, T., and Barrand, N. E.: Glacier change from the early Little Ice Age to 2005 in the Torngat Mountains, northern Labrador, Canada, Geomorphology, 246, 558-569, doi:10.1016/j.geomorph.2015.07.006, 2015.

Zhang, X., Vincent, L. A., Hogg, W. D., and Niitsoo, A.: Temperature and precipitation trends in Canada during the 20th century, Atmos.-Ocean, 38, 395-429, doi:10.1080/07055900.2000.9649654, 2000. 